\title{
Molecular Characterization of a Saposin-Like Protein Family Member Isolated from Bovine Lymphocytes
}

\author{
L. M. Sordillo, ${ }^{1}$ J. T. Kendall, ${ }^{2}$ C. M. Corl, ${ }^{2}$ and T. H. Cross ${ }^{2}$ \\ ${ }^{1}$ Large Animal Clinical Sciences, College of Veterinary Medicine, Michigan State University, East Lansing 48824 \\ ${ }^{2}$ Department of Veterinary Science, Penn State University, University Park 16802
}

\begin{abstract}
Human and porcine $\mathrm{T}$ lymphocytes and natural killer (NK) cells produce antibacterial proteins that belong to the saposin-like family of proteins (SAPLIP). The objective of this study was to determine if a bovine homolog of SAPLIP exists in lymphocytes that exhibit antibacterial activity. Following stimulation with IL2 , bactericidal activity against Staphylococcus aureus was detected to some extent in most major subpopulations of $\mathrm{T}$ lymphocytes including $\mathrm{CD} 4^{+}, \mathrm{CD}^{+}, \mathrm{CD}^{+}$, and $\mathrm{WC}^{+} \gamma \delta \mathrm{T}$ lymphocytes. However, the majority of antibacterial activity was observed in the $\mathrm{CD} 2^{+} \mathrm{CD}^{-}$ lymphocytes, which are similar phenotypically to NK cells. A partial sequence of a bovine SAPLIP was generated using low specificity primers designed from regions of homology between other SAPLIP including porcine NK-lysin and human granulysin. Enhanced expression of the bovine lysin gene was detected in mRNA isolated from IL-2-stimulated $\mathrm{CD}^{+} \mathrm{CD}^{-}$lymphocytes. The partial cDNA sequence was then used to make gene specific primers for a rapid amplification of cDNA ends (RACE) procedure that provided repeatable $5^{\prime}$ and $3^{\prime}$ cDNA ends. By examining overlapping regions from the RACE procedure, full-length sequence information was obtained for the bovine lysin homologue. Conceptual translation of the cDNA demonstrated conserved similarities to known SAPLIP members. Further characterization of the bovine lysin may facilitate its use in protecting dairy cattle against bacterial infections.
\end{abstract}

(Key words: saposin-like, lymphocyte, bovine)

Abbreviation key: CF = cell free, GSP = gene-specific
primers, HBSS = Hank's balanced salt solution, NK =
natural killer, ORF = open reading frame, PBMC =
peripheral blood mononuclear cells, QC RT-PCR =
quantitative competitive reverse transcription PCR,

Received August 30, 2004

Accepted November 29, 2004.

Corresponding author: Lorraine M. Sordillo; e-mail: sordillo@ msu.edu.
RACE = rapid amplification of cDNA ends, SAPLIP = saposin-like protein, TIGR = The Institute for Genomic Research.

\section{INTRODUCTION}

Lymphocytes are able to recognize antigens through specific membrane receptors that define the immunological characteristics of specificity, diversity, memory, and self/nonself recognition. Researchers have shown that there are at least 2 major lymphocyte subpopulations present in bovine tissues and secretions, $T$ and B lymphocytes, that differ in function and protein products (Sordillo and Streicher, 2002). The T lymphocytes can be subdivided further into either $\alpha \beta$ T lymphocytes, which include $\mathrm{CD} 4^{+}$(T-helper lymphocytes) and $\mathrm{CD}^{+}$(T-cytotoxic or T-suppressor) lymphocytes, or $\gamma \delta \mathrm{T}$ lymphocytes. Depending on stage of lactation and tissue location, the percentages of these cells can vary significantly in dairy cattle. For example, lower percentages of $\alpha \beta \mathrm{T}$ lymphocytes during the postpartum period were associated closely with diminished mitogen-stimulated proliferation and spontaneous cytotoxic activity when compared with $\alpha \beta$ T lymphocyte populations obtained from midlactation cows. It also was shown that bovine $\mathrm{CD} 4^{+}$lymphocytes primarily express a T-helper-2 phenotype (i.e., characteristic of humoral immunity) during the periparturient period and a T-helper-1 phenotype (i.e., characteristic of a cell-mediated immunity) at midlactation (ShaferWeaver and Sordillo, 1996). Changes in the composition of blood and mammary gland mononuclear cell populations have been linked with heightened susceptibility to infectious diseases in dairy cattle including mastitis and Johne's disease (Kehrli et al., 1989). These findings indicate that the alterations in the overall phenotypic profiles of lymphocyte populations may affect the functional capacity of the immune system and possibly increase the cow's susceptibility to microbial challenge.

Whereas compositional changes in bovine lymphocyte populations with respect to lactation stage and disease susceptibility are well characterized, it is significant to note that the functional significance of spe- 
cific lymphocyte subpopulations is not defined fully. The majority of previous work has focused on the involvement of lymphocyte populations in orchestrating an effective, adaptive (i.e., humoral and cellular) immune response. Involvement of nonspecific soluble and cellular mechanisms in the defense against bacterial pathogens has primarily focused on that which was mediated by phagocytic cell populations including macrophages and neutrophils (Sordillo and Streicher, 2002). By comparison, considerably less is known about the nonspecific defensive role of bovine lymphocyte populations against the spectrum of bacterial pathogens capable of causing disease. However, research has shown that cytokine-stimulated porcine and human $\mathrm{T}$ lymphocytes and natural killer (NK) cells are capable of nonspecific killing of bacteria through the secretion of the proteins porcine NK-lysin and human granulysin, respectively (Andersson et al., 1995b, 1996a, 1999; Pena and Krensky, 1997). A parasitic protozoan of the human intestinal tract, Entamoeba histolytica, also kills bacteria through the generation of a pore-forming protein, amoebopore (Bruhn and Leippe, 1999). Despite the considerable evolutionary distance between single-celled parasitic organisms and mammalian lymphocytes, the bactericidal effector proteins porcine NK-lysin, human granulysin, and amoebopore all are members of same protein family, the saposin-like proteins (SAPLIP). The SAPLIP are small glycoproteins, often derived from larger precursor proteins in vivo, which carry out diverse functions through association with lipid membranes (Munford et al., 1995). The amino acid sequences of family members include highly conserved cysteine residues that form disulfide bonds and give SAPLIPs a stable structure, whereas their secondary protein structure consists mainly of $\alpha$-helices joined by loops (Munford et al., 1995; Andreu et al., 1999). Previous research demonstrated that cytokine-stimulated bovine lymphocytes also possess antibacterial activity in vitro that is not major histocompatibility complex restricted (Sordillo et al., 1991; Shafer-Weaver and Sordillo, 1996). The objective of the current study was to determine if a bovine homologue (bovine lysin) to human granulysin or porcine NK lysin is expressed in lymphocyte subpopulations that possess antibacterial activity.

\section{MATERIALS AND METHODS}

\section{Isolation of Mononuclear Cells}

Peripheral blood mononuclear cells (PBMC) were isolated from 6 midlate lactating Holstein dairy cows. All experimental cows were free of mastitis and in their third or fourth lactation. Mononuclear cells were isolated and purified as previously described (Sordillo et al., 1991). Purified cells were washed 3 times in Hank's balanced salt solution (HBSS; Sigma Chemical Co., St. Louis, MO) and suspended in PBS containing 2\% BSA (Sigma Chemical Co.). Mononuclear cell-enriched preparations contained more than 95\% mononuclear cells as determined by Wright's Giemsa staining and were more than $95 \%$ viable as assessed by trypan-blue exclusion.

\section{Cell Separation Using Magnetic Beads}

To identify the effector phenotype responsible for bactericidal activity, lymphoid subpopulations were isolated from PBMC using the VarioMACS separation system (Miltenyi Biotech Inc., Sunnyvale, CA). The VarioMACS isolation yielded both enriched $(+)$ and depleted (-) cultures of a given lymphoid subpopulation. Cell cultures for CD2 ( $\alpha \beta$ T lymphocytes and NK cells, BAQ95A), CD4 (T-helper, CACT83B), CD8 (Tcytotoxic/suppressor, CACT80C), WC1 ( $\gamma \delta$ T lymphocytes, B7A1), and B2 (B lymphocytes, BAQ44A) were obtained using the respective monoclonal antibody (VMRD, Pullman, WA) as described previously (Shafer-Weaver and Sordillo, 1996). Briefly, isolated lymphoid cells $\left(1 \times 10^{7}\right)$ were incubated with individual monoclonal antibodies $\left(10 \mu \mathrm{L} / 1 \times 10^{7}\right.$ cells $)$ for $30 \mathrm{~min}$ at $4^{\circ} \mathrm{C}$. The cells were then washed with PBS and incubated for an additional $30 \mathrm{~min}$ at $4^{\circ} \mathrm{C}$ with $10 \mu \mathrm{g}$ of goat-antimouse Ig-coated magnetic beads (Miltenyi Biotech) per $10^{7}$ target cells. The bead-cell complex was then extracted from noncomplexed cells using a magnetic field and the positive (enriched) and negative (depleted) fractions were collected. The purity of the subsets was $>97 \%$ as determined by flow cytometric analysis. To obtain an NK-cell enriched population, $\mathrm{CD} 2^{+} \mathrm{CD} 3^{-}$cells were isolated by first collecting a CD3 ${ }^{-}$ fraction and then selecting for $\mathrm{CD} 2^{+}$cells. For use in the bactericidal assay, enriched (+) and depleted (-) cultures of individual lymphoid phenotypes were incubated for $48 \mathrm{~h}$ in the presence of recombinant human IL-2 or the absence of this cytokine as previously described (Sordillo et al., 1991; Shafer-Weaver and Sordillo, 1996).

\section{Flow Cytometric Analysis}

Flow cytometric analysis was performed as previously described to characterize the phenotype of antibacterial effector cells and to ensure isolation procedures yielded lymphoid populations (Sordillo et al., 1991). All monoclonal antibodies (VMRD) were at a stock concentration of $1 \mathrm{mg} / \mathrm{mL}$ and diluted: CD2 $(\alpha \beta$ T lymphocytes and NK cells, BAQ95A at 1:100), CD4 
(T-helper, CACT83B at 1:160), CD8 (T-cytotoxic/suppressor, CACT80C at 1:400), surface IgM (B-lymphocytes, BAQ44A at 1:100), WC1 ( $\gamma \delta$ T-lymphocytes, B\& $\mathrm{A} 1$ at 1:200), major histocompatibility complex class II (TH14B at 1:200), granulocytes/monocytes (DH59B at 1:100), IL-2R ( $\alpha$-chain, CACT116A at 1:200), and A2 (activated CD8 lymphocytes, CACT77A at 1:100). An irrelevant antigen control CD18 (H20A at 1:100) was run in parallel to detect nonspecific labeling of fluorescein isothiocyanate-labeled $\mathrm{F}_{2}$ goat antimouse Ig. Analyses were performed with a Coulter EPICS PS 753 flow cytometer (Coulter Electronics, Miami, FL) and immunofluorescence histograms were expressed as percentage of positive-staining cells.

\section{Bactericidal Activity of Effector Cells}

Bactericidal activity of the PBMC cultures against Staphylococcus aureus (strain Newbold 305) was evaluated. Stock bacterial cultures were stored at $-70^{\circ} \mathrm{C}$, and fresh inocula for each experiment were thawed, plated on blood agar, and incubated for $24 \mathrm{~h}$ at $37^{\circ} \mathrm{C}$. Resulting colonies then were incubated in UHT-processed milk for $6 \mathrm{~h}$ at $37^{\circ} \mathrm{C}$. Bacterial concentration was enumerated as previously described (Sordillo et al., 1991). Briefly, duplicate 10 -fold dilutions were plated on blood agar and incubated at $37^{\circ} \mathrm{C}$ overnight to determine bacterial concentration. The bacterial suspension was then washed and suspended to a final concentration of $5 \times 10^{4} \mathrm{cfu} / \mathrm{mL}$ in HBSS and effector cells were suspended to $5 \times 10^{5}$ cells $/ \mathrm{mL}$ in HBSS. All bactericidal assays were performed in duplicate and entailed direct contact between effector cells and bacteria as previously described (Sordillo et al., 1991). Briefly, equal amounts of the bacterial and cell suspensions, along with control cultures of bacterial suspension only, were gently mixed at $37^{\circ} \mathrm{C}$ for 30,60 , and 90 min preceding sonification of the mixture. The percentage of bacteria killed was measured by plating duplicate 10-fold dilutions of the experimental cultures onto blood agar. Bactericidal activity was computed from the following formula: Percentage of bactericidal activity: [1 - (colony-forming units of effector bacterial culture)] / (colony-forming units of bacterial culture) $\times 100$.

Additional assays were conducted to determine if the lymphocytes required contact with the microbial target and to evaluate the spectrum of antibacterial activity. For these studies, the cell-free $(\mathbf{C F})$ culture supernatants from IL-2-stimulated $\mathrm{CD}^{+} \mathrm{CD}^{-}$lymphocyte subpopulations were evaluated in 2 ways. Commercially available porous membrane inserts (Millicell-CM, Millipore, Bedford, MA) were used to separate bacteria from bovine lymphoid cells in an incubation chamber. The incubation proceeded for 30 min after which the bactericidal activity was assessed as described previously (Sordillo et al., 1991). In addition, CF supernatants were collected from IL-2-stimulated $\mathrm{CD} 2^{+} \mathrm{CD}^{-}$lymphocytes by filter sterilization following a 30-min incubation with an equal volume of bacterial suspension $\left(5 \times 10^{4} \mathrm{cfu} / \mathrm{mL}\right)$. The antibacterial activity of the CF supernatant was assessed against Staph. aureus, Escherichia coli, and Streptococcus uberis as described above. Briefly, $50 \mu \mathrm{L}$ of bacterial culture $\left(5 \times 10^{4} \mathrm{cfu} / \mathrm{mL}\right)$ was incubated with 450 $\mu \mathrm{L}$ of the CF supernatant or HBSS for 30 min before being plated onto blood agar.

\section{RNA Isolation}

Cultures enriched for whole $\mathrm{PBMC}, \mathrm{CD}^{+}$, and $\mathrm{CD}^{+} \mathrm{CD}^{-}$lymphoid cells were suspended in RPMI$1640\left(1 \times 10^{7}\right.$ cell $\left.\mathrm{s} / \mathrm{mL}\right)$ containing $10 \%$ heat-inactivated fetal bovine serum (Hyclone, Logan, UT), 1\% antibiotic-antimycotic solution (Sigma Chemical Co.), and 1\% L-glutamine (Sigma Chemical Co.). The cultures were then stimulated with $100 \mathrm{U} / \mathrm{mL}$ of recombinant human IL-2 (Roche Molecular, Mannheim, Germany) for $48 \mathrm{~h}$ at $37^{\circ} \mathrm{C}$. Control, unstimulated cultures also were incubated for $48 \mathrm{~h}$ at $37^{\circ} \mathrm{C}$. After incubation, the cells were washed with HBSS, suspended $(5.0 \times$ $10^{6}$ cells $/ \mathrm{mL}$ ) in TRIZOL reagent (Invitrogen, Carlsbad, CA), and total RNA was isolated per manufacturer's directions (Chomczynski and Sacchi, 1987). Using the PolyATract mRNA Isolation System IV (Promega, Madison, WI), mRNA was isolated from the total RNA of IL-2-stimulated lymphocytes. The isolated RNA and mRNA were measured using $\mathrm{A}_{260}$ (Beckman DU 650, Beckman Instruments, Inc., Fullerton, CA) and stored at $-70^{\circ} \mathrm{C}$ before use.

\section{Generation of the Bovine SAPLIP Partial Sequence}

Primer sets (Table 1) were designed to determine if a sequence for bovine SAPLIP could be isolated from IL-2 stimulated bovine $\mathrm{CD}^{+} \mathrm{CD}^{-}$lymphocytes. The gene-specific primer (GSP) sets were designed using a bovine lymphocyte-derived sequence [The Institute for Genomic Research (TIGR) database accession \#TC265765 and \#TC265766, formerly \#TC90773] developed from cDNA pooled from various tissues with strong homology to porcine NK-lysin (NCBI\#X85431). The reverse transcription reaction was carried out in a final volume of $20 \mu \mathrm{L}$, using $1 \mu \mathrm{g}$ of RNA and $1 \mu M$ of recombinant murine leukemia virus reverse transcriptase (Promega). The resulting cDNA was used as a template in PCR reactions using the designed GSP.

The PCR reactions using GSP were carried out in a final volume of $50 \mu \mathrm{L}$ and were heated to $95^{\circ} \mathrm{C}$ for a 
Table 1. Primer sequences for bovine lysin based on regions of homology with known saposin-like protein family members. ${ }^{1}$

\begin{tabular}{llll}
\hline Primer set & Sequence & $\begin{array}{l}\text { Annealing } \\
\text { temperature }\end{array}$ & $\begin{array}{l}\text { Product } \\
\text { size }\end{array}$ \\
\hline Optimal & $\begin{array}{l}\text { Forward 5'-GACGGCCCATCTGTGTGATGGAGAC-3' } \\
\text { Reverse 5'-TCAGCAGCCTCATCTTGCTGCACAC-3' }\end{array}$ & $72^{\circ} \mathrm{C}$ & $215 \mathrm{bp}$ \\
Product \#1 & $\begin{array}{l}\text { Forward 5'-GGCCCATCTGTGTGATGGAGACGAG-3' } \\
\text { Reverse 5'-CGGGCTGATCTCCCAACTTGTCCAT-3' }\end{array}$ & $72^{\circ} \mathrm{C}$ & $155 \mathrm{bp}$ \\
Product \#2 & $\begin{array}{l}\text { Forward 5'-GTGATGGAGACGAGTTGTGCCAGGG-3' } \\
\text { Reverse 5'-TCAGCAGCCTCATCTTGCTGCACAC-3' }\end{array}$ & $72^{\circ} \mathrm{C}$ & $201 \mathrm{bp}$ \\
Product \#3 & $\begin{array}{l}\text { Forward 5'-GTGATGGAGACGAGTTGTGCCAGGG-3' } \\
\text { Reverse 5'-CGGGCTGATCTCCCAACTTGTCCAT-3' }\end{array}$ & $72^{\circ} \mathrm{C}$ & $144 \mathrm{bp}$ \\
Product \#4 & $\begin{array}{l}\text { Forward 5'-CAGCTGCCTCAACATGACCTCCTGG-3' } \\
\text { Reverse 5'-CCCTGGCACAACTCGTCTCCATCAC-3' }\end{array}$ & $72^{\circ} \mathrm{C}$ & $147 \mathrm{bp}$ \\
Product \#5 & $\begin{array}{l}\text { Forward 5'-CAGCTGCCTCAACATGACCTCCTGG-3' } \\
\text { Reverse 5'-CGGGCTGATCTCCCAACTTGTCCAT-3' }\end{array}$ & $72^{\circ} \mathrm{C}$ & $266 \mathrm{bp}$ \\
\hline
\end{tabular}

${ }^{1}$ Primers were designed using the SDSC Molecular Biology Workbench program (www.biowb.sdsc.edu) and The Institute for Genomic Research database bovine cDNA sequence TC90773 as a template. Each primer set was successful in amplifying the target sequence when used in reverse transcription-PCR with bovine $\mathrm{CD} 2^{+} \mathrm{CD}^{-}$lymphocyte RNA.

cycle of 3 min and then cycled 30 times through a 30 s denaturing step at $95^{\circ} \mathrm{C}$, a 30 -s annealing step at $72^{\circ} \mathrm{C}$, and a 1-min elongation step at $72^{\circ} \mathrm{C}$ in a PTC200 DNA Engine heated lid PCR thermocycler (MJ Research, Watertown, MA). Following the final cycle, an extension step at $72^{\circ} \mathrm{C}$ for 5 min was included. The PCR products were excised from a $1.5 \%$ gel stained with ethidium bromide preceding purification using the QIAquick Gel Slice purification kit (Qiagen, Valencia, CA). The resulting product was ligated into pGEM T-Easy plasmid vector (Promega), transformed into competent DH5 $\alpha$ E. coli (Invitrogen), and plated onto selection agar. Plasmids were purified from individual colonies using a plasmid mini-prep system (Promega) and sequenced. The sequences obtained were aligned with the bovine SAPLIP homologue sequence using the CLUSTALW alignment program (www.workbench.sdsc.edu) and compared with the GenBank database using BLAST (NCBI, Washington, DC).

\section{Quantitative Competitive Reverse Transcription-PCR}

The relative expression of bovine lysin transcripts by IL-2-stimulated and unstimulated bovine lymphoid cell cultures was compared using quantitative competitive reverse transcription PCR (QC RTPCR). Forward and reverse primers specific for bovine lysin were designed from the partial known sequence using DNAstar PrimerSelect software (Table 1). Internal standards consisted of recombinant RNA (rcRNA) and were constructed as previously described (Vanden Heuvel et al., 1994). Briefly, each forward rcRNA primer contained sequences of the $\mathrm{T} 7$ promoter, target
mRNA forward primer, and spacer-gene forward primer ( $\beta$-globulin). Each reverse primer contained sequences of the spacer-gene reverse primer, target mRNA reverse primer, and poly $(\mathrm{dT})_{18}$. The PCR reaction for internal standards was carried out in a final volume of $50 \mu \mathrm{L}$ with $200 \mathrm{ng}$ of human genomic DNA (Promega) and contained $3 \mathrm{mM} \mathrm{MgCl}, 0.2 \mathrm{~m} M$ each of dNTP, 30 pmol each of rcRNA forward and reverse primers, and 2.5 U of Taq polymerase (Promega). The reactions were heated to $94^{\circ} \mathrm{C}$ then subjected to a 30 s annealing step at $59^{\circ} \mathrm{C}$, and a 45 -s extension step at $72^{\circ} \mathrm{C}$. Following the final cycle, an additional extension step at $72^{\circ} \mathrm{C}$ for 5 min was included. The products were purified (Wizard PCR Prep, Promega) and transcribed into rcRNA using an in vitro transcription system (Riboprobe System-T7, Promega). Quantitative competitive RT-PCR was performed as previously described (Vanden Heuvel et al., 1994). The reactions were heated to $94^{\circ} \mathrm{C}$ for $3 \mathrm{~min}$, and cycled 30 times through a 45 -s denaturing step at $95^{\circ} \mathrm{C}$, a 1-min annealing step at $72^{\circ} \mathrm{C}$, and a 1 -min extension step at $72^{\circ} \mathrm{C}$ (Robocycler Gradient 96, Stratagene, La Jolla, CA). Following the final cycle, an extension step at $72^{\circ} \mathrm{C}$ for $5 \mathrm{~min}$ was included. The RT-PCR products were visualized using a $2 \%$ agarose gel stained with ethidium bromide. Relative mRNA transcript expression was measured by a densitometry system (Eagle Eye II, Stratagene) and quantified as previously described (Vanden Heuvel et al., 1994). The absence of contaminating DNA from the sample RNA preparations was confirmed by running $\mathrm{RT}$ reactions without $\mathrm{RT}$ enzyme, a process that resulted in no band formation. 


\section{Rapid Amplification of cDNA Ends}

Whole bovine RNA isolated from IL-2 stimulated and unstimulated $\mathrm{CD} 2^{+} \mathrm{CD}^{-}$lymphocytes was used as template for the GeneRacer rapid amplification of cDNA ends (RACE) kit (Invitrogen) that facilitated the enzymatically assisted degradation of contaminating RNA in the samples while selecting for full-length, capped mRNA. Both 5' and 3' RACE-ready cDNA sequences were generated by converting $1 \mu \mathrm{g}$ of the fulllength mRNA to cDNA via a first-strand cDNA synthesis reaction. A positive control for the generation of the $5^{\prime}$ and $3^{\prime}$ RACE-ready cDNA populations was performed using control RNA from HeLa cells. Firststrand synthesis reactions (total volume $=20 \mu \mathrm{L}$ ) were incubated at $85^{\circ} \mathrm{C}$ for $15 \mathrm{~min}$ to inactivate the murine leukemia virus-RT and then stored at $-20^{\circ} \mathrm{C}$ until use.

The RACE-ready mRNA was used in $5^{\prime}$ and $3^{\prime}$ RACE reactions. The $5^{\prime}$ RACE product was generated using the indicated PCR mix, the GeneRacer $5^{\prime}$ universal primer, and the bovine SAPLIP optimal reverse primer. The $3^{\prime}$ RACE product was generated using the indicated PCR mix, the GeneRacer $3^{\prime}$ universal primer, and the bovine SAPLIP optimal forward primer. Reactions were heated to $94^{\circ} \mathrm{C}$ for $2 \mathrm{~min}$ and then cycled 3 times through a $30-$ s denaturing step at $94^{\circ} \mathrm{C}$ and a 3 -min annealing step at $72^{\circ} \mathrm{C}$; cycled 10 times through a 30 -s step at $94^{\circ} \mathrm{C}$, a 30 -s step at $70^{\circ} \mathrm{C}$, and a 3 -min step at $72^{\circ} \mathrm{C}$; cycled 20 times through a 30 -s step at $94^{\circ} \mathrm{C}$, a 30 -s step at $68^{\circ} \mathrm{C}$, and a 3 -min step at $72^{\circ} \mathrm{C}$; and cycled once through a 10 -min step at $72^{\circ} \mathrm{C}$ using a PTC-200 DNA Engine (MJ Research). The resulting products were visualized using a $1.5 \%$ agarose gel stained with ethidium bromide.

Both the $5^{\prime}$ and $3^{\prime}$ RACE products were ligated into pGEM T-Easy plasmid vector (Promega) and transformed into competent DH5 $\alpha$ E. coli (Invitrogen). Following plasmid purification, the sequences obtained were aligned with the bovine SAPLIP homologue sequence using the CLUSTALW alignment program (www.workbench.sdsc.edu) and compared with the GenBank database using BLAST (NCBI, Washington, DC). The secondary structure of the protein was predicted using the PredictProtein Server (www.emblheidelberg.de).

\section{Statistical Analyses}

Determination of isolated lymphoid cell phenotypes and bactericidal data was analyzed by least squares analyses of variance using the GLM procedures of SAS (SAS Institute Inc., Cary, NC). Statistical analysis included the effects of cow, culture, stimulation, and culture $\times$ stimulation. Preplanned comparisons of least squares means from the overall model were made by paired $t$-tests. Means were contrasted between stimulation. For the flow cytometry analysis after $48 \mathrm{~h}$ incubation, statistical analysis was determined by Student's $t$-test. Differences were accepted as significant when $P<0.05$. Data for the QC RT-PCR were analyzed by Student's $t$-test for differences between bovine SAPLIP mRNA expression by unstimulated whole $\mathrm{PBMC}, \mathrm{CD}^{+}$, and $\mathrm{CD}^{+}{ }^{+} \mathrm{CD} 3^{-}$lymphocyte cultures and IL-2 stimulated whole PBMC, $\mathrm{CD}^{+}$, and $\mathrm{CD}^{+} \mathrm{CD}^{-}$ lymphocyte cultures. Differences were accepted as significant when $P<0.05$.

\section{RESULTS}

\section{Phenotypic Characterization of Bactericidal Lymphoid Cultures}

The VarioMACS system was used to phenotypically separate different lymphocyte populations with specific monoclonal antibodies to define which lymphocyte subpopulations are responsible for bactericidal activity. This system yielded both enriched (+) and depleted (-) cultures of a given phenotype without affecting cell functions. Each of the culture populations was assayed independently for bactericidal activity. The bactericidal ability of the various lymphocyte subpopulations is summarized in Table 2. Whereas unstimulated cultures of CD2 ${ }^{+}$lymphocytes ( $\alpha \beta$ T lymphocytes and NK cells) demonstrated significantly greater $(P<0.05)$ killing of Staph. aureus bacteria than their $\mathrm{CD}^{-}$counterparts, stimulation with IL-2 significantly $(P<0.01)$ enhanced the bactericidal ability in these cultures. Our data support the possibility that $\mathrm{CD} 2^{+}$cells, which consist of $\alpha \beta$-T lymphocytes and NK cells, may be the primary effector cells responsible for bactericidal functions.

To determine which subpopulation of $\mathrm{CD}^{+}$lymphocytes are the major effector population, additional cell sorting protocols of $\alpha \beta \mathrm{T}$ cells were performed. At this time, specific monoclonal antibodies for bovine NK cells are not available; therefore, we were unable to obtain enriched (+) NK cultures to directly assess their bactericidal ability. Within the T-lymphocyte subpopulations, cultures positive for $\mathrm{CD}^{+}$(T-helper), $\mathrm{CD} 8^{+}$ (T-cytotoxic/suppressor), and $\mathrm{CD}^{+}$(T-cell receptor) exhibited significantly $(P<0.05)$ less bactericidal ability compared with their depleted $\left(\mathrm{CD}^{-}, \mathrm{CD}^{-}, \mathrm{CD}^{-}\right)$ counterparts. Although antibody binding to the CD3 molecule can activate these cell types, it did not enhance bactericidal activity by $\mathrm{CD}^{+}$cultures. Unstimulated cultures depleted of these phenotypes ( $\mathrm{CD}^{-}$, $\mathrm{CD}^{-}$, and $\mathrm{CD}^{-}$) exhibited some antibacterial activity, which was enhanced by IL-2 stimulation. Cytokine stimulation significantly enhanced bactericidal ability in $\mathrm{CD}^{-}(P<0.05)$ and $\mathrm{CD}^{-}(P<0.01)$ cultures. Cul- 
Table 2. Bactericidal activity expressed by enriched and depleted peripheral blood lymphocytes.

\begin{tabular}{lrr}
\hline & \multicolumn{2}{c}{ Bactericidal activity $^{2}$} \\
\cline { 2 - 3 } Surface antigen $^{1}$ & \multicolumn{1}{c}{ Unstimulated $^{3}$} & \multicolumn{1}{c}{ IL-2 $^{4}$} \\
\hline CD2 $^{+}$ & $12.3 \pm 3.5^{\mathrm{a}}$ & $37.3 \pm 3.5^{\mathrm{a} * *}$ \\
$\mathrm{CD}^{-}$ & $1.9 \pm 3.5^{\mathrm{b}}$ & $2.1 \pm 3.3^{\mathrm{b}}$ \\
$\mathrm{CD} 4^{+}$ & $10.0 \pm 3.5^{\mathrm{b}}$ & $17.6 \pm 3.5^{\mathrm{b}}$ \\
$\mathrm{CD}^{-}$ & $25.6 \pm 3.5^{\mathrm{a}}$ & $32.5 \pm 3.5^{\mathrm{a}}$ \\
$\mathrm{CD}^{+}$ & $9.0 \pm 2.3^{\mathrm{b}}$ & $9.7 \pm 2.3^{\mathrm{b}}$ \\
$\mathrm{CD}^{-}$ & $19.9 \pm 2.3^{\mathrm{a}}$ & $32.7 \pm 2.3^{\mathrm{a} * *}$ \\
$\mathrm{CD}^{+}$ & $4.7 \pm 3.0^{\mathrm{b}}$ & $9.3 \pm 3.0^{\mathrm{b}}$ \\
$\mathrm{CD}^{-}$ & $16.4 \pm 3.0^{\mathrm{a}}$ & $25.6 \pm 3.0^{\mathrm{a} *}$ \\
$\mathrm{~B}^{+}$ & $1.0 \pm 3.3^{\mathrm{b}}$ & $5.7 \pm 3.3^{\mathrm{b}}$ \\
$\mathrm{B}^{-}$ & $11.3 \pm 4.0^{\mathrm{a}}$ & $23.0 \pm 4.0^{\mathrm{a} *}$ \\
$\mathrm{WC1}^{+}$ & $6.0 \pm 4.0^{\mathrm{b}}$ & $9.6 \pm 4.0^{\mathrm{b}}$ \\
WC1 $^{-}$ & $13.0 \pm 4.0^{\mathrm{a}}$ & $25.4 \pm 4.0^{\mathrm{a} *}$ \\
\hline
\end{tabular}

${ }^{\mathrm{a}, \mathrm{b}}$ Significantly different with respect to cell population within a stimulation group $(P<0.05)$.

${ }^{1}$ Cells with the "-" superscript are depleted of that specific cell subset. Cells with the "+" superscript are enriched phenotype cultures $(\geq 97 \%)$.

${ }^{2}$ Cultures were incubated for $30 \mathrm{~min}$ with bacterial-effector cell contact. Bactericidal activity is expressed as least square means \pm standard error.

${ }^{3}$ Effector cells were incubated for $48 \mathrm{~h}$ in the absence of cytokine stimulation.

${ }^{4}$ Effector cells were incubated for $48 \mathrm{~h}$ with recombinant human IL-2.

*Significantly different with respect to stimulation within a cell population $(P<0.05)$.

**Significantly different with respect to stimulation within a cell population $(P<0.01)$.

tures enriched for B lymphocytes and $\mathrm{WC} 1^{+} \gamma \delta \mathrm{T}$ lymphocytes did not exhibit significant bactericidal activity, compared with $\mathrm{CD}^{+}$, even following IL-2 stimulation.

\section{Soluble Factor Produced by Bovine Lymphoid Cells}

The bactericidal activity expressed by isolated $\mathrm{CD} 2^{+} \mathrm{CD} 3^{-}$lymphocytes in the absence of effector-target cell contact is summarized in Figure 1. The purpose of this experiment was to observe if bovine lymphoid cells could produce a soluble factor that is capable of bactericidal activity. This was approached using 2 methods. The first approach used a mesh screen to separate the effector cell from the target cell. Both unstimulated and IL-2-stimulated cultures exhibited bactericidal activity. The second approach allowed the effector and bacteria cells to contact one another, after which the bactericidal activity was measured using the CF supernatants. Regardless of the approach used, a significant increase in bactericidal activity was observed following IL-2 stimulation with the 30-min cultures.

\section{Spectrum of Antibacterial Activity}

The antibacterial capabilities of CF supernatants from $\mathrm{CD}^{+} \mathrm{CD}^{-}$lymphocyte populations were tested against several mastitis-causing pathogens including Streptococcus uberis, E. coli, and Staph. aureus. The CF supernatants displayed killing activity against all the pathogens tested (Table 3). Based on the broad spectrum of antibacterial activity, it was hypothesized that certain populations of bovine lymphocytes may express bovine lysin, a SAPLIP family member.

\section{Generation of the Bovine SAPLIP Partial Sequence}

Six GSP sets (Table 1) were designed to amplify partial sequences of a putative bovine lysin, successfully generating PCR fragments of the expected size (144 to $266 \mathrm{bp}$ ) using $\mathrm{CD} 2^{+} \mathrm{CD} 3^{-} \mathrm{RNA}$ as template. The PCR products were cloned using pGEM T-Easy plasmid vector and sequence analysis was performed. Alignment (using CLUSTALW) of the cloned PCR products with the TIGR database sequence revealed a high degree of homology, indicating that the bovine lysin mRNA is produced by bovine $\mathrm{CD} 2^{+} \mathrm{CD} 3^{-}$lymphocytes. A BLAST search on the cloned PCR products showed strong homology with SAPLIP family members, specifically porcine NK-lysin and human granulysin. These results indicate that, when bovine NKlike lymphocyte RNA is used as a template, the GSP can amplify a putative bovine SAPLIP with homology to other SAPLIP family members.

\section{Bovine Lysin Transcript Expression}

Using QC RT-PCR procedures, we were able to demonstrate that the $\mathrm{CD} 2^{+} \mathrm{CD}^{-}$lymphoid populations expressed the bovine SAPLIP transcript (bovine lysin) in the presence or absence of IL-2. In the unstimulated cultures, the $\mathrm{CD} 2^{+} \mathrm{CD}^{-}$lymphocytes expressed more of the bovine lysin transcript than the $2 \mathrm{CD}^{+}$subpopulations or the whole (PBMC) population (Figure 2). Following stimulation of the lymphoid cultures with IL-2 $(100 \mathrm{U} / \mathrm{mL})$, the $\mathrm{CD}^{+} \mathrm{CD}^{-}$population of lymphoid cells expressed significantly $(P<0.01)$ more of the bovine lysin transcript, an effect not observed in the whole or $\mathrm{CD}^{+}$lymphoid populations. Such a significant difference in the IL-2-stimulated $\mathrm{CD} 2^{+} \mathrm{CD} 3^{-}$population compared with the whole or $\mathrm{CD}^{+}$populations clearly shows that IL-2 enhances production of bovine lysin from $\mathrm{CD}^{+} \mathrm{CD}^{-}$lymphocytes.

\section{Rapid Amplification of cDNA Ends}

The proposed full-length open reading frame (ORF) for bovine lysin was generated using the $3^{\prime}$ and $5^{\prime}$ 


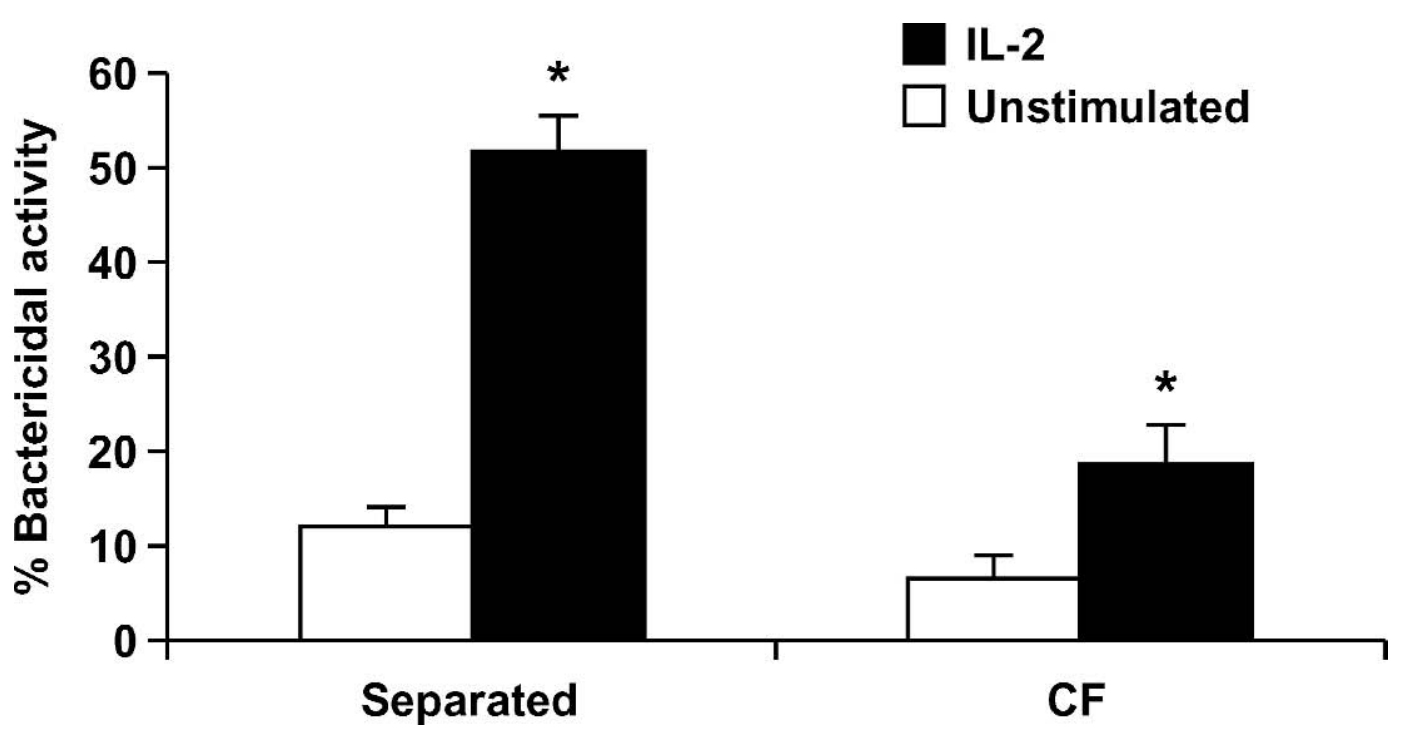

Figure 1. Bactericidal activity expressed by isolated $\mathrm{CD} 2^{+} \mathrm{CD} 3^{-}$lymphocytes in the absence of effector-target cell contact. Effector lymphocytes were separated from Staphylococcus aureus by a $0.40-\mu \mathrm{m}$ mesh screen (separated) during incubation or cell-free (CF) culture supernatants were collected from lymphocyte/bacterial cocultures and then screened for killing activity. The effector CD2 ${ }^{+} \mathrm{CD} 3^{-}$lymphocytes were unstimulated or stimulated with recombinant human IL-2 for $48 \mathrm{~h}$ before exposure to bacteria. Bactericidal activity is expressed as least squares means of the percentage killing of Staph. aureus \pm SEM. *Significantly different with respect to IL-2 treatment $(P<0.01)$ $(\mathrm{n}=3)$.

RACE reaction in conjunction with the GSP previously tested. The $3^{\prime}$ and $5^{\prime}$ RACE reactions yielded products of 392 and $319 \mathrm{bp}$, respectively, with no amplification of extraneous products (Table 4). These RACE products were cloned into pGEM T-easy vector and sequence analysis was performed. When aligned, the $3^{\prime}$ and $5^{\prime}$ RACE products overlapped for a sequence of 79 bp. Further sequence analysis yielded a full-length sequence of $632 \mathrm{bp}$ with an ORF of $441 \mathrm{bp}$ for bovine lysin that contained both start and stop codons.

Table 3. Antibacterial activity of cytokine-stimulated $\mathrm{CD}^{+} \mathrm{CD}^{-}$ lymphocytes against various mastitis-causing pathogens.

\begin{tabular}{lll}
\hline Pathogen & Strain & $\begin{array}{l}\text { Antibacterial } \\
\text { activity }^{1}\end{array}$ \\
\hline Staphylococcus aureus & Newbold 305 & $37 \%$ \\
Streptococcus uberis & MB21LR & $28 \%$ \\
Escherichia coli & 487 & $31 \%$ \\
\hline
\end{tabular}

${ }^{1}$ Bacterial cultures were suspended at $5 \times 10^{4} \mathrm{cfu} / \mathrm{mL}$ in Hank's balanced salt solution (HBSS), and $50 \mu \mathrm{L}$ of each strain was incubated with $450 \mu \mathrm{L}$ of the antibacterial fraction, collected by HPLC from the ammonium sulfate precipitated $\mathrm{CD} 2^{+} \mathrm{CD}^{-}$cell culture supernatant, for $30 \mathrm{~min}$. Control tubes containing bacterial strains and ammonium sulfate precipitant of culture media without $\mathrm{CD}^{+} \mathrm{CD}^{-}$lymphocytes or bacterial strains with HBSS only were run in parallel. After incubation, samples were plated onto blood agar and antibacterial activity was calculated as percentage cfu from experimental tubes compared with the controls (there was no difference in the recovery of viable bacteria between control tubes of HBSS or culture media).

\section{Homology of Bovine Lysin to Known SAPLIP Members}

A nucleotide BLAST search showed that our ORF has significant homology to NK-lysin mRNA (NCBI\# $\mathrm{X}$ 85431) and granulysin mRNA (NCBI\# XM 002560). However, it has been noted that SAPLIP family members often have more homology at the protein level. Therefore, conceptual translation of the ORF produced a 147-residue protein that was tested for homology to known SAPLIP members through BLAST and sequence alignment. A BLAST search yielded proteins with homology to the translated ORF, including NKlysin (NCBI\# CAA59720) and granulysin (NCBI\# XP 002560) (Table 5). Alignment using CLUSTALW showed that the bovine lysin ORF shares $60 \%$ homology with NK-lysin and 37\% homology with granulysin. The full-length ORF for bovine lysin is predicted to have a molecular weight of $16 \mathrm{kDa}$, whereas the predicted molecular weight of NK-lysin is $13.4 \mathrm{kDa}$ and that of granulysin is $15 \mathrm{kDa}$. The active forms of these SAPLIP are the products of posttranslational cleavage of the larger preprotein (Table 5). In both proteins, the cleaved form contains a SAPLIP region that is defined by the presence of conserved residues. Importantly, a homologous SAPLIP region was detected in the carboxy terminal portion of the bovine protein. The SAPLIP region of the bovine protein is predicted 


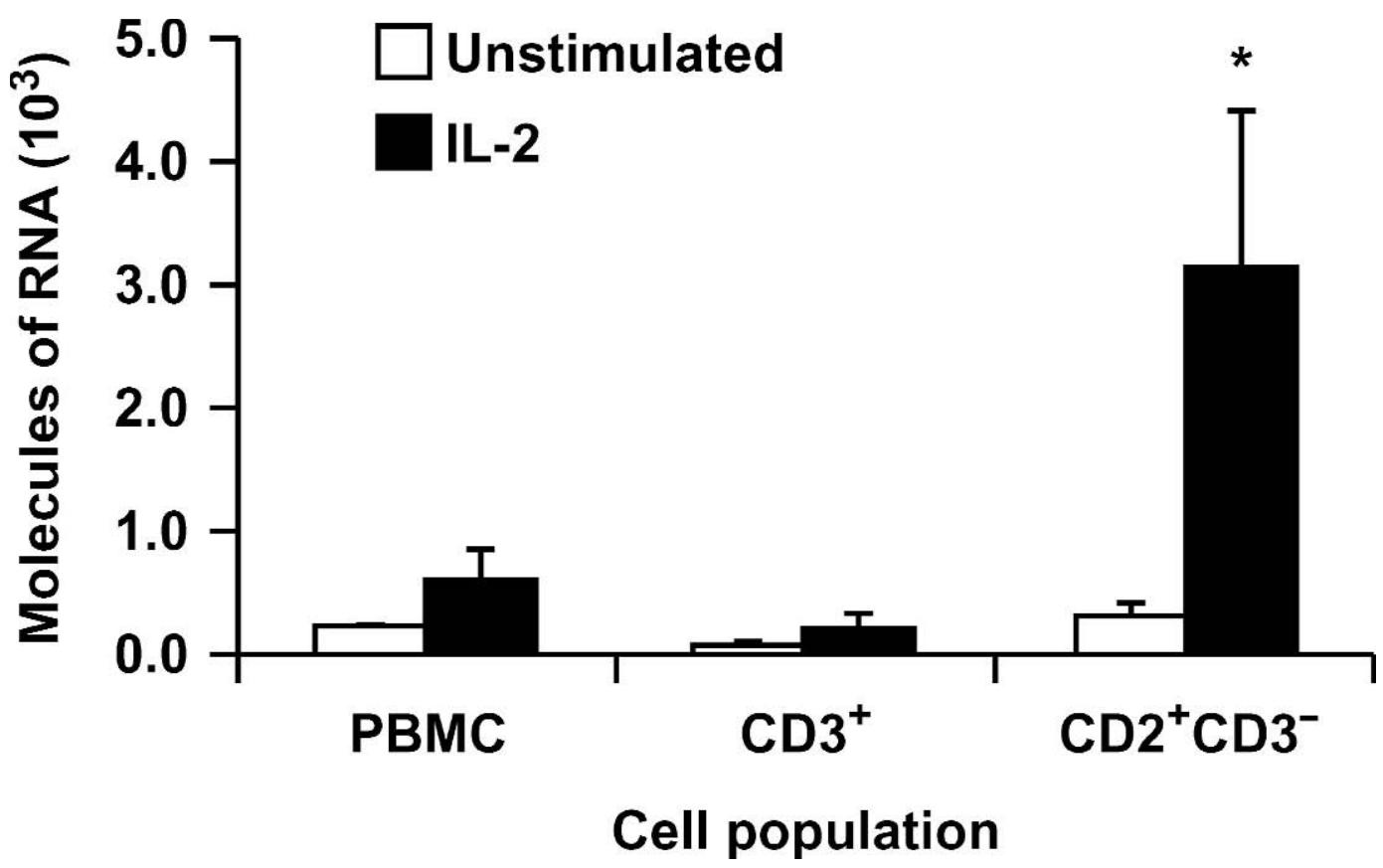

Figure 2. Quantitative competitive reverse transcription-PCR (QC RT-PCR) was performed to detect bovine lysin mRNA expression in bovine lymphocytes. Open bars represent bovine lysin expression from unstimulated lymphoid cell populations and the filled bars represent bovine lysin mRNA expression from IL-2 stimulated lymphoid cell populations. The absence of contaminating DNA from the sample RNA preparations was confirmed by running RT reactions without RT enzyme that resulted in no band formation. The cell populations consisted of whole peripheral blood mononuclear cells (PBMC), $\mathrm{CD}^{+}{ }^{+}$enriched lymphocytes, and $\mathrm{CD} 2^{+} \mathrm{CD} 3^{-}$-enriched lymphocytes. ${ }^{*}$ Significantly different with respect to IL-2 treatment $(P<0.01)(\mathrm{n}=3)$.

to have a molecular weight of $9.4 \mathrm{kDa}$ compared with $9.35 \mathrm{kDa}$ for NK-lysin and $9.5 \mathrm{kDa}$ for granulysin. This was indicated through the presence of 6 cysteine residues that are positionally conserved among SAPLIP family members (Table 6).

Conceptual translation of this SAPLIP region of the bovine $9.4 \mathrm{kDa}$ ORF using the PredictProtein server (www.embl-heidelberg.de) reveals important second- ary structural homology between the protein and other SAPLIP. The translated SAPLIP region of the bovine lysin sequence displays considerable conservation of the amino acids that are implicated in helix formation in NK-lysin (Table 7). The bovine lysin is predicted to be $69.0 \% \alpha$-helices, and is defined as having an "all $\alpha$ helix" formation. Furthermore, NK-lysin and granulysin also are predicted to be "all $\alpha$-helix", with 75.9

Table 4. Alignment of $5^{\prime}$ and $3^{\prime}$ rapid amplification of cDNA ends (RACE) products generated from a partial bovine lysin sequence. ${ }^{1}$

\begin{tabular}{|c|c|}
\hline $\begin{array}{l}\text { 5'RACE-AGCTGCCTTAACATGACCTCCTGGGCTGTCCTGATCATCACCTCGGTGCTCCT } \\
\text { GGTTGCCCCAGGGCTGGCTTTTTCCGGTCTGACTCCTGAGAGCCACGACCAGGCGACGGC } \\
\text { CCATCTATGTGATGGAGACGAGTTGTGCCAGGGACTGGCCCTGGAGGATCCCCAGGGTGA } \\
\text { CCTGCTGCTCCAAGGAGAAGAGCTGAGCCTACGATGTGGTTCTTGTCGGAGAATAATACA }\end{array}$ & $\frac{53}{113}$ \\
\hline $\begin{array}{l}\text { 3'RACE-ATGGACAAGTTGGGAGATCAGCCCGATGAGAATACCGTTATCGAGGAGGCCTC } \\
\text { ACATCTGATGGACAAGTTGGGAGATCAGCCCGATGAGAATACCGTTATCGAGGAGGCCTC }\end{array}$ & \\
\hline $\begin{array}{l}\text { CAAGGTGTGCAGCAAGATGAGGCTGCTGAAAGGTCTGTGCAAGTCAATCATGAAGAAATT } \\
\text { CAAGGTGTGCAGCAAGATGAGGCTGC }\end{array}$ & \\
\hline $\begin{array}{l}\text { TCTCCGTACCATCGCTGAGGACATCGTAGCTGGAAAAACCTCTCAGGTTATCTGTGTGGA } \\
\text { CATCAAGATGTGCAAAAGCAAGCCAGTAGGTTTCATTTGATTCCCTGGGTCCTCTTACCC } \\
\text { CATCCTGGGGAAAAAGCACAGAAACTCCAGTATTCCTTGGCCCGGCTCCCTTCTTCCTGA } \\
\text { ATCCAGGAGTCTTCTCTCCAGTTTCTGGCACCAAACTCCCTTCACTGCCTTTCCCTCTCA } \\
\text { GAATAAAATATTCATGCAAGAAAAAAAAAAAAAAAAAAA }\end{array}$ & \\
\hline
\end{tabular}

\footnotetext{
${ }^{1}$ Gene-specific primers for a partial bovine saposin-like protein (SAPLIP) sequence were used in a RACE reaction with RNA isolated from $\mathrm{CD} 2^{+} \mathrm{CD} 3^{-}$lymphocytes. The RACE 632 -bp bovine lysin sequence was derived by alignment of the resulting $5^{\prime}$ (321 bp, bold text) and $3^{\prime}$ (386 bp, plain text) RACE products. There is a conserved region of $79 \mathrm{bp}$ overlap that was used for alignment of the sequences and generation of a 632-bp full-length sequence. The putative open reading frame (ORF) of bovine lysin is underlined. Indicated ORF possesses $75 \%$ homology to the porcine NK-lysin ORF (NCBI\# X85431) and 61\% homology to the human granulysin ORF (NCBI \# XM 002560).
} 
Table 5. Alignment of translated open reading frames of putative bovine saposin-like protein (bSAPLIP), NK-lysin, and granulysin. ${ }^{1}$

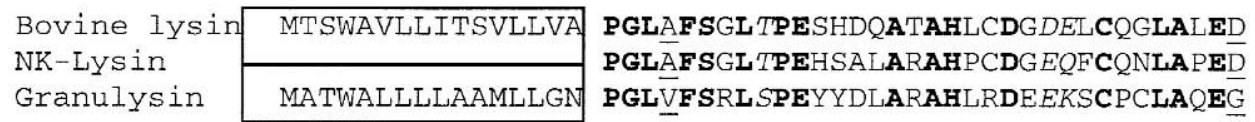

PQGDLLLQGEEL^ ^SLRCGSCRRI IQHLMDKLGDQPD ENTVI EEASKVCSKMR-LLKGLCKS IMK PQGDQLIQREEL^GLICESCRKI IQKLEDMVGPQPNED IVTQAASRVCDKMK-ILRG VC KKIM $R$ PQGDILLTKTQEL^ ARDYRTCLTI VQKLKKMV-DKPTQRSVSNAATRVCRTGRSRWRDVCRNFMR

KF'LRTIAEDIVAGKTSRVICVDIKMCKSKPVGF I TFLRR ISKDILTGKKP $Q A$ ICVD IKICKEK-TGLI RYQSRVTQG $L V A \mathbf{G} E$ TA $Q Q I \mathbf{C E D} L R L \mathbf{C I P} \underline{\underline{S}}-\underline{T} \mathbf{G P} L$ and $69.9 \% \alpha$-helices, respectively. The PredictProtein GLOBE program defines bovine lysin, as well as porcine NK-lysin and human granulysin, as having compact, globular protein conformations.

\section{DISCUSSION}

Human granulysin and porcine NK-lysin are antimicrobial proteins that exhibit a broad range of killing activity against a variety of microorganisms including gram-positive and gram-negative bacteria, fungi, protozoa, and parasites (Andreu et al., 1999; Stenger et al., 1999; Wang et al., 2000; Andra et al., 2003). The expression of both granulysin and NK-lysin can be induced following mitogenic or antigenic stimulation of T lymphocytes and increased in NK cells following exposure to cytokines (Andersson et al., 1996a; Krensky, 2000). In earlier studies, we showed that IL-2stimulated bovine lymphocytes possess antibacterial activity that is not restricted to the major histocompatibility complex (Sordillo et al., 1991; Shafer-Weaver and Sordillo, 1996). Consistent with our earlier findings and those reported for the human and porcine effector molecules (Andersson et al., 1996a; Krensky, 2000 ), the results from this trial suggest that the majority of antibacterial activity following cytokine stimulation is by a T lymphocyte-depleted population with NK cell characteristics $\left(\mathrm{CD}^{+} \mathrm{CD}^{-}\right)$. Whereas several

Table 6. Proposed cysteine-to-cysteine disulfide bridge formation pattern for 9 -kDa bovine lysin. ${ }^{1}$

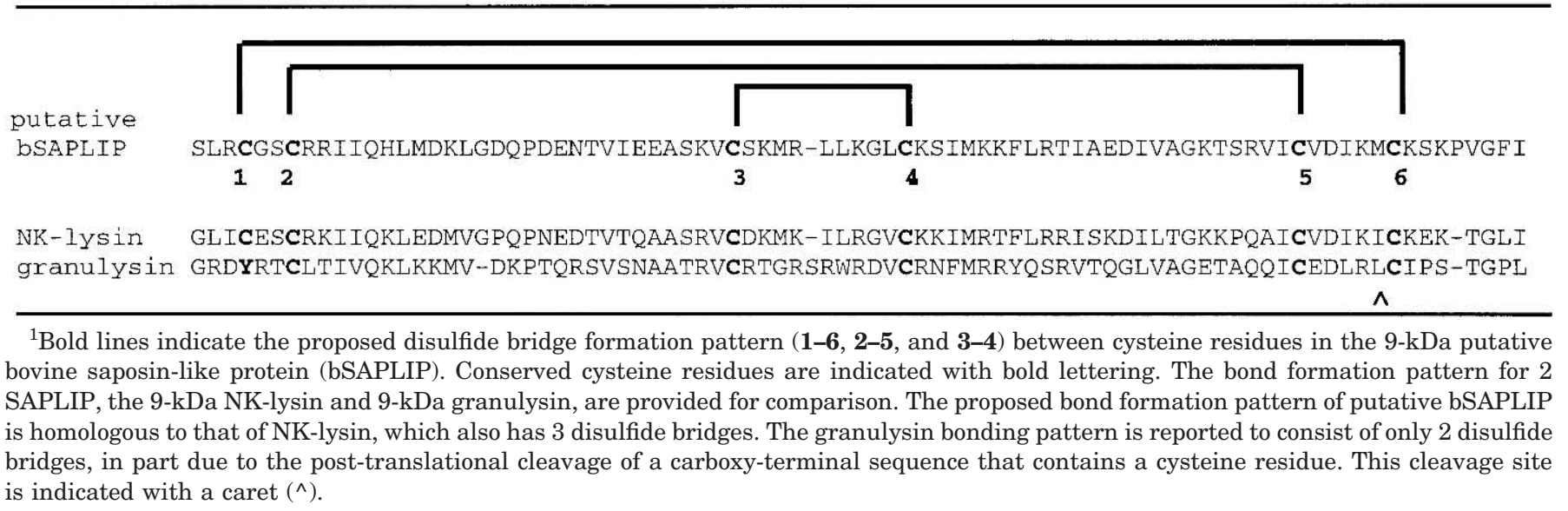


Table 7. Hydrophobic regions and proposed $\alpha$-helices of 9 -kDa bovine lysin. ${ }^{1}$

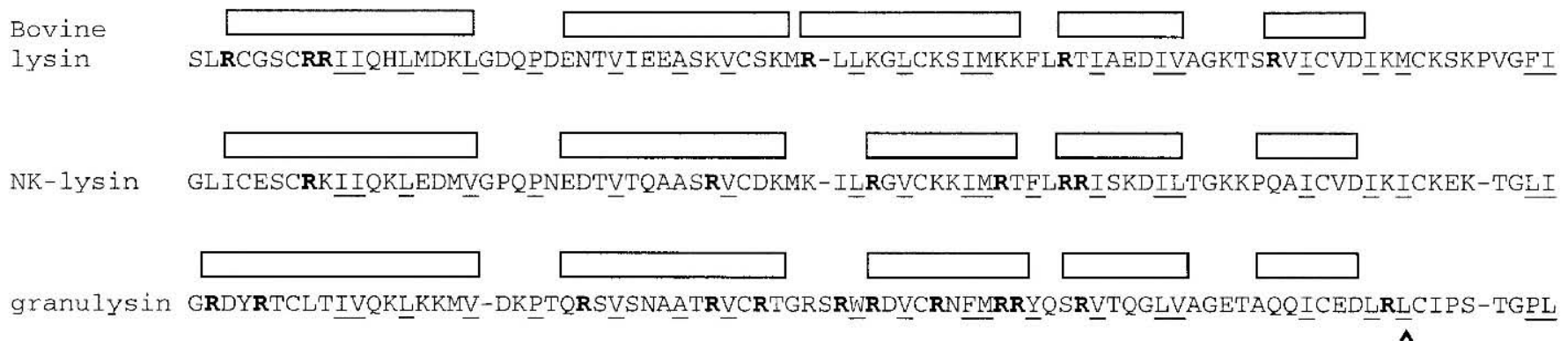

${ }^{1}$ Boxes indicate the proposed $\alpha$-helical regions in the 9-kDa putative bovine saposin-like protein (bSAPLIP). The $\alpha$-helical regions of 2 SAPLIP, the 9-kDa NK-lysin, and 9-kDa granulysin, are provided for comparison, and the proposed $\alpha$-helical regions of putative bSAPLIP are homologous to them. $\alpha$-Helical regions have been shown to be important to killing activity in the SAPLIP. The granulysin $\alpha$-helices have been described previously (Bruhn and Leippe, 1999). Positively charged arginine residues are indicated with bold lettering. These residues have been shown to be intrinsic to membrane binding and killing activity in recombinant granulysin. Conserved hydrophobic residues $(\mathrm{V}, \mathrm{I}, \mathrm{L}, \mathrm{P}, \mathrm{A}, \mathrm{W}, \mathrm{M}, \mathrm{F}$, and $\mathrm{Y}$ ) are underlined. These residues play a role in amphipathic $\alpha$-helix formation and SAPLIP folding. The carboxy-terminal cleavage site of granulysin is indicated with a caret $\left({ }^{\wedge}\right)$.

other major subsets of Tlymphocytes $\left(\mathrm{CD} 4^{+}\right.$and $\left.\mathrm{CD} 8^{+}\right)$ exhibited some antibacterial activity, it does not appear that B lymphocytes are a cellular source of this novel effector function. Previous studies by others have shown that human and porcine antibacterial effector proteins are present not only in NK cells, but also in T lymphocytes expressing CD4, CD8, and $\gamma \delta$ TCR surface markers (Andersson et al., 1995b; Krensky, 2000; Dieli et al., 2001). However, our results suggest that the WC1 $+\gamma \delta$ T lymphocytes do not possess antibacterial activity following IL-2 stimulation. Because the previous studies used mycobacterial antigen stimulation to induce granulysin expression in $\gamma \delta \mathrm{T}$ lymphocytes (Dieli et al., 2001), our conflicting findings may be a function of the stimuli used to express the effector molecule. Detailed information on the stimuli required to induce SAPLIP expression in various cell populations is limited and warrants further investigation.

The ability to obtain a highly purified population of lymphoid cells that express the majority of nonspecific killing activity facilitated subsequent studies to characterize the effector molecule. Several experiments were conducted in this study to show that the antibacterial factor can be secreted from the $\mathrm{CD}^{+} \mathrm{CD}^{-}$lymphocyte populations and that the killing activity is not dependent on contact between the effector and target cells. Previous studies showed that the mechanism of antibacterial activity associated with SAPLIP family members involves the release of effector molecules from the cytoplasmic granules of $\mathrm{T}$ lymphocytes and NK cells. It is the release of granulysin and NK lysin during degranulation that facilitates the subsequent lysis of microbial membranes by electrostatic charge disruption (Miteva et al., 1999; Anderson et al., 2003). Other similarities with the known SAPLIP family members (Andersson et al., 1995b; Kumar et al., 2001) include the fact that the bovine lysin molecule has a broad spectrum antimicrobial activity against both gram-positive and gram-negative pathogens suggesting an important role in nonspecific defense against bacterial infections. These data provide evidence that the bovine antibacterial effector molecule associated with certain lymphocyte populations may be a member of the SAPLIP family.

Effective PCR primers for porcine NK-lysin were developed based on the sequence homology it shares with human granulysin (Andersson et al., 1996a). Therefore, the TIGR database of bovine cDNA was searched for a bovine homologue to other members of SAPLIP. The search resulted in an 1157-bp cDNA (\#TC90773, now \#TC265765 and \#TC265766), which contained a region of strong homology to granulysin and NK-lysin. Furthermore, this sequence was originally isolated from bovine lymphoid tissue, indicating that the cellular source is consistent for other mammalian SAPLIP family members. This region of homology within the TIGR sequence was used as a template for the generation of putative bovine SAPLIP PCR primers that were subsequently successful in generating the desired product when used in an RT-PCR with RNA from bovine $\mathrm{CD}^{+} \mathrm{CD}^{-}$lymphocytes. Several GSP sets amplified a single, distinct band of product that varied between 144 and 266 bp in length, and was the expected size in relation to the primer placement on the putative bovine SAPLIP from the TIGR database. Cloning and subsequent sequencing revealed that the amplified products were $100 \%$ homolo- 
gous to the putative bovine SAPLIP found within the TIGR database. The sum of these observations indicates that mRNA for a putative bovine SAPLIP is produced in $\mathrm{CD}^{+} \mathrm{CD}^{-}$effector cell populations capable of killing bacterial targets.

The GSP that were successful in amplifying a partial bovine lysin product were subsequently used as primers in both 5' and $3^{\prime}$ RACE reactions. When aligned using CLUSTALW, the $5^{\prime}$ and $3^{\prime}$ RACE product displayed a conserved overlap region of $79 \mathrm{bp}$. The alignment yielded a putative full-length bovine lysin cDNA sequence of $632 \mathrm{bp}$, including a polyadenosine tail region of $22 \mathrm{bp}$. Overall, this cDNA is somewhat smaller than the cDNA of NK-lysin (780 bp) and granulysin (738 bp). It should be noted, however, that the alignment of the RACE products resulted in a cDNA with only $12 \mathrm{bp}$ of sequence $5^{\prime}$ of the putative start codon, whereas NK-lysin and granulysin have 195 and 128 bp, respectively, $5^{\prime}$ of their start codons. This indicates that the 5' RACE reaction may not have been entirely successful in fully mapping the bovine lysin, but it is not clear if this was due to variability in the RACE reaction or to a difficulty inherent in our bovine template, such as the formation of secondary structures. In spite of these differences in length, the derived nucleotide sequence of bovine lysin is $68 \%$ homologous to NK-lysin (NCBI\# X85431) and 62\% homologous to granulysin (NCBI \# XM 002560).

An ORF of $441 \mathrm{bp}$ that contains a methionine start codon was detected within the bovine lysin sequence. The ORF for granulysin also contains a methionine start codon, whereas the sequence for NK-lysin has a putative methionine start codon. Importantly, it should be noted that the length (441 bp) of the ORF for the bovine lysin is quite comparable to that of the NK-lysin (416 bp) and granulysin (393 bp) ORF. Furthermore, the bovine lysin ORF possesses $75 \%$ homology to the NK-lysin ORF and $61 \%$ homology to the granulysin ORF. These data indicated that the fulllength ORF for bovine lysin had been identified.

The ORF for bovine lysin shares considerable sequence homology with the cDNA sequences of other SAPLIP family members. Translational analysis confirmed that the amino acid sequence of the protein further displayed defining characteristics of the SAPLIP family. Many SAPLIP, including granulysin and NK-lysin, exist in vivo in a number of forms that are differentiated by posttranslational modifications (Andersson et al., 1995b; Pena and Krensky, 1997). Granulysin originates as a large preprotein form, which is then modified to produce a $15-\mathrm{kDa}$ protein, which is again cleaved to generate the active $9-\mathrm{kDa}$ form of granulysin (Hansonet et al., 1999). The bovine lysin ORF also has an amino-terminal sequence of 14 amino acids, (5'-MTSWAVLLITSVLL- $3^{\prime}$ ), that shares conservation of strong groups and 50\% homology with a predicted hydrophobic leader sequence in preprotein granulysin (Hanson et al., 1999). In the available sequence for NK-lysin, this leader sequence is absent, but in granulysin, this sequence is thought to be cleaved to produce the $15-\mathrm{kDa}$ form of the protein. When the homologous leader sequence is conceptually cleaved in a similar manner from the bovine lysin protein, a $16-\mathrm{kDa}$ form of the protein is produced. A BLAST search of this $16-\mathrm{kDa}$ bovine protein indicates considerable homology of $60 \%$ with NK-lysin with conservation of a number of individual residues, whereas similar alignment shows only $37 \%$ homology between bovine lysin and the $15-\mathrm{kDa}$ form of granulysin. Interestingly, a sequence of 11 amino acids located at the amino-terminal end of the bovine protein shares $100 \%$ homology with NK-lysin and $72 \%$ homology with granulysin, perhaps indicating a conserved role for the sequence in cellular processing or protein function.

The result of the cleavage events and posttranslational modifications is the generation of stable, mature, roughly $9-\mathrm{kDa}$ forms of human granulysin and porcine NK-lysin. Within their carboxy-terminal regions are the cysteines and hydrophobic residues that define the SAPLIP domain, a conserved pattern detected throughout the SAPLIP family of proteins. These cysteine residues generate disulfide bridges that are important for SAPLIP secondary structure and function (Andersson et al., 1996b). When the bovine lysin amino acid sequence is aligned with the $9-\mathrm{kDa}$ granulysin and NK-lysin, this conserved SAPLIP region pattern is evident. The putative $9.4-\mathrm{kDa}$ form of bovine lysin contains 6 cysteine residues that have $100 \%$ conserved alignment with the 6 cysteine residues in NK-lysin. Therefore, the proposed order of cysteine disulfide bridge formation for bovine lysin is the same as that of NK-lysin (Andersson et al., 1995a,b). Five of the bovine lysin cysteine residues align with residues in granulysin, and the sixth aligns with a granulysin tyrosine (Y) residue. Although the possible significance of this residue is not known, it was shown that the nucleotide difference between tyrosine and cysteine is limited to $1 \mathrm{bp}$ (Pena et al., 1997).

The conserved amino acid residues present in the mammalian SAPLIP family members result in secondary protein conformations rich in $\alpha$-helices, connected by loop regions, and stabilized by disulfide bridges (Andersson et al., 1995b; Munford et al., 1995; Pena et al., 1997). The $\alpha$-helices are amphipathic in nature because of the presence of hydrophobic and hydrophilic residues. The combination of disulfide bridges and amphipathic regions results in a globular protein that is 
very compact and exhibits a characteristic SAPLIP fold, with hydrophilic outer residues and hydrophobic inner residues (Munford et al., 1995). Using the PredictProtein server, we characterized the structure of the $9.4-\mathrm{kDa}$ form of bovine lysin, the $9.35-\mathrm{kDa}$ form of NK-lysin, and the 9.5-kDa form of granulysin. Porcine NK-lysin was defined as having 75.9\% $\alpha$-helices and $24.1 \%$ loop regions, a conformation that was termed "all $\alpha$ " by the program. Granulysin was defined as having $69.9 \% \alpha$-helices and $30.1 \%$ loop regions, and was defined as "all $\alpha$ ". Bovine lysin was defined as having $69.0 \% \alpha$-helices and $30.9 \%$ loop regions, scores considerably close to those found for the SAPLIP, and resulting in an "all $\alpha$ " designation for the protein. In addition, all 3 proteins were predicted to have a compact, globular conformation, which is in agreement with previous characterization of SAPLIP family members (Munford et al., 1995).

The relative importance of $\alpha$-helices for the functioning of porcine NK-lysin and human granulysin has been established. Recombinant granulysin peptides that represent helix-loop-helix regions were found to exhibit strong bactericidal activity against $E$. coli and Mycobacterium tuberculosis, whereas regions without helices lacked activity (Wang et al., 2000). Subsequent destruction of positively charged arginine residues within the $\alpha$-helices resulted in greatly reduced binding of the proteins to E. coli and M. tuberculosis and abrogation of killing (Wang et al., 2000). This indicates that the specific interaction of positively charged SAPLIP residues with the negatively charged target cell phospholipid membrane may be of considerable importance for killing activity. Positively charged surface residues in NK-lysin have been implicated in a suggested mechanism for SAPLIP killing activity; molecular electroporation (Miteva et al., 1999). Through this mechanism, transient binding of a cationic, $\alpha$ helical protein with a negatively charged phospholipid membrane generates an electrical field that destabilizes the membrane, resulting in osmotic lysis (Miteva et al., 1999). This mechanism could explain the broadspectrum killing activity exhibited by SAPLIP members that seems to result from a transient disruption of target cell membranes without traditional pore formation. The Protein Calculator program (www.scripps.edu/cgi-bin/cdputnam/protcalc) was used to determine the charge at $\mathrm{pH} 7.00$ of the 9 - $\mathrm{kDa}$ forms of NKlysin, granulysin, and bovine lysin. The NK-lysin had a predicted charge of 8.7 , granulysin had a charge of 10.8 , and bovine lysin had a charge of 8.0. These results confirm the overall cationic character of each protein that is believed to result from the positive residues observed in the amino acid sequences. The cationic charge of bovine lysin is comparable to those of
NK-lysin and granulysin, and may further implicate molecular electroporation as a possible mechanism for the bactericidal activity.

\section{CONCLUSION}

In this study, a bovine homologue to human granulysin and porcine NK lysin was identified and characterized. A product of IL-2-stimulated bovine lymphocytes displayed several functional characteristics similar to other mammalian SAPLIP members. The fulllength sequence of the bovine homologues to NK-lysin and granulysin was identified using gene databases and molecular techniques. When aligned with NK-lysin and granulysin, the bovine lysin exhibited conserved cysteine residues that are responsible for the disulfide bonds and which contribute to the stability, protein conformation, and killing activity of the SAPLIP family members. The bovine protein shares a motif of hydrophobic residues that partially contribute to the generation of amphipathic $\alpha$-helices and, presumably, a characteristic "SAPLIP fold". These findings indicate that the newly identified nucleotide sequence, when translated, will produce a bovine protein that is compact, rich in amphipathic $\alpha$-helices, and cationic. Bovine lysin may represent an important nonspecific defense mechanism against bacterial infections in dairy cattle.

\section{ACKNOWLEDGMENTS}

This work was supported, in part, by an endowment from the Matilda R. Wilson Fund (Detroit, MI) and the Michigan Animal Initiative Industry Coalition.

\section{REFERENCES}

Anderson, D. H., M. R. Sawaya, D. Cascio, W. Ernst, R. Modlin, A. Krensky, and D. Eisenberg. 2003. Granulysin crystal structure and a structure-derived lytic mechanism. J. Mol. Biol. 325:355-365.

Andersson, M., T. Curstedt, H. Jornvall, and J. Johansson. 1995a. An amphipathic helical motif common to tumourolytic polypeptide NK-lysin and pulmonary surfactant polypeptide SP-B. FEBS Lett. 362:328-332.

Andersson, M., R. Girard, and P. Cazenave. 1999. Interaction of NK lysin, a peptide produced by cytolytic lymphocytes, with endotoxin. Infect. Immun. 67:201-205.

Andersson, M., H. Gunne, B. Agerberth, A. Boman, T. Bergman, B. Olsson, A. Dagerlind, H. Wigzell, H. G. Boman, and G. H. Gudmundsson. 1996a. NK-lysin, structure and function of a novel effector molecule of porcine T and NK cells. Vet. Immunol. Immunopathol. 54:123-126.

Andersson, M., H. Gunne, B. Agerberth, A. Boman, T. Bergman, R. Sillard, H. Jornvall, V. Mutt, B. Olsson, H. Wigzell, H. G. Boman, and G. H. Gudmundsson. 1995b. NK-lysin, a novel effector peptide of cytotoxic T and NK cells. Structure and cDNA cloning of the porcine form, induction by interleukin 2 , antibacterial and antitumour activity. EMBO J. 14:1615-1625.

Andersson, M., A. Holmgren, and G. Spyrou. 1996b. NK-lysin, a disulfide-containing effector peptide of T-lymphocytes, is re- 
duced and inactivated by human thioredoxin reductase. Implication for a protective mechanism against NK-lysin cytotoxicity. J. Biol. Chem. 271:10116-10120.

Andra, J., R. Herbst, and M. Leippe. 2003. Amoebapores, archaic effector peptides of protozoan origin, are discharged into phagosomes and kill bacteria by permeabilizing their membranes. Dev. Comp. Immunol. 27:291-304.

Andreu, D., C. Carreno, C. Linde, H. G. Boman, and M. Andersson. 1999. Identification of an anti-mycobacterial domain in NK-lysin and granulysin. Biochem. J. 344:845-849.

Bruhn, H., and M. Leippe. 1999. Comparative modeling of amoebapores and granulysin based on the NK-lysin structure-structural and functional implications. Biol. Chem. 380:1001-1007.

Chomczynski, P., and N. Sacchi. 1987. Single-step method of RNA isolation by acid guanidinium thiocyanate-phenol-chloroform extraction. Anal. Biochem. 162:156-159.

Dieli, F., M. Troye-Blomberg, J. Ivanyi, J. J. Fournie, A. M. Krensky, M. Bonneville, M. A. Peyrat, N. Caccamo, G. Sireci, and A. Salerno. 2001. Granulysin-dependent killing of intracellular and extracellular Mycobacterium tuberculosis by Vgamma9/Vdelta2 T lymphocytes. J. Infect. Dis. 184:1082-1085.

Hanson, D. A., A. A. Kaspar, F. R. Poulain, and A. M. Krensky. 1999. Biosynthesis of granulysin, a novel cytolytic molecule. Mol. Immunol. 36:413-422.

Kehrli, M. E., B. J. Nonnecke, and J. A. Roth. 1989. Alterations in bovine lymphocyte function during the periparturient period. Am. J. Vet. Res. 50:215-220.

Krensky, A. M. 2000. Granulysin: A novel antimicrobial peptide of cytolytic T lymphocytes and natural killer cells. Biochem. Pharmacol. 59:317-320.

Kumar, J., S. Okada, C. Clayberger, and A. M. Krensky. 2001. Granulysin: A novel antimicrobial. Expert Opin. Investig. Drugs 10:321-329.

Miteva, M., M. Andersson, A. Karshikoff, and G. Otting. 1999. Molecular electroporation: a unifying concept for the description of membrane pore formation by antibacterial peptides, exemplified with NK-lysin. FEBS Lett. 462:155-158.

Munford, R. S., P. O. Sheppard, and P. J. O'Hara. 1995. Saposinlike proteins (SAPLIP) carry out diverse functions on a common backbone structure. J. Lipid Res. 36:1653-1663.

Pena, S. V., D. A. Hanson, B. A. Carr, T. J. Goralski, and A. M. Krensky. 1997. Processing, subcellular localization, and function of 519 (granulysin), a human late $\mathrm{T}$ cell activation molecule with homology to small, lytic, granule proteins. J. Immunol. 158:2680-2688.

Pena, S. V., and A. M. Krensky. 1997. Granulysin, a new human cytolytic granule-associated protein with possible involvement in cell-mediated cytotoxicity. Semin. Immunol. 9:117-125.

Shafer-Weaver, K. A., and L. M. Sordillo. 1996. Enhancing bactericidal activity of bovine lymphoid cells during the periparturient period. J. Dairy Sci. 79:1347-1352.

Sordillo, L. M., M. Campos, and L. A. Babiuk. 1991. Antibacterial activity of bovine mammary gland lymphocytes following treatment with interleukin-2. J. Dairy Sci. 74:3370-3375.

Sordillo, L. M., and K. L. Streicher. 2002. Mammary gland immunity and mastitis susceptibility. J. Mammary Gland Biol. Neoplasia $7: 135-146$.

Stenger, S., J. P. Rosat, B. R. Bloom, A. M. Krensky, and R. L. Modlin. 1999. Granulysin: A lethal weapon of cytolytic T cells. Immunol. Today 20:390-394.

Vanden Heuvel, J. P., G. C. Clark, M. C. Kohn, A. M. Tritscher, W. F. Greenlee, G. W. Lucier, and D. A. Bell. 1994. Dioxin-responsive genes: examination of dose-response relationships using quantitative reverse transcriptase-polymerase chain reaction. Cancer Res. 54:62-68.

Wang, Z., E. Choice, A. Kaspar, D. Hanson, S. Okada, S. C. Lyu, A. M. Krensky, and C. Clayberger. 2000. Bactericidal and tumoricidal activities of synthetic peptides derived from granulysin. J. Immunol. 165:1486-1490. 